\title{
SOUTH AFRICA: THE ARDUOUS TASK OF FACING OUR RELIGIOUS PAST
}

\section{ABSTRACT}

The term 'rainbow nation' tends to soften both the intensity and divergence of the complex mixture of origins, languages, ideologies, cultures, lifestyles and skills of the South African society. With Christians totalling more than $80 \%$ of the population and the Church recognised as the strongest non-government organization, one apparent exception to these differences is religion. However, incapacitated by their past, Afrikaners were unable to respond positively during the critical stages of transformation and find themselves marginalized, at the edge of the 'rainbow nation'.

Evading confrontation with the past or constantly postponing it while waiting for the current crises to subside is no longer an option. This article attempts to identify unresolved issues from the history, culture and theology of Afrikaners that form obstacles in the way of positive development and progress. Facing these issues is the prerequisite to identifying and implementing remedial actions in order to find new direction and life.

\section{INTRODUCTION}

In theory, South Africans should have been able to live normal lives by now, with the rainbow nation celebrating improved quality of life for everyone. However, most South Africans would agree that day-to-day living in the 'new' South Africa is not for the faint-hearted. The collapse of service delivery, the explosion in social problems like prostitution, unemployment, poverty, and corruption as well as the skyrocketing number of incidents related to crime, violence, xenophobia and the continuing ravage of HIV/AIDS turned the dreams of millions of South Africans into a 'national nightmare with no end in sight' (Nowicki 2004). According to Nytagodien and Neal (2004:375, 376), the sense of malaise and despair and acts of violence can be seen as remnants of collective traumas from the past.

Dr Erna Oliver, Department of Christian Spirituality, Church History and Missiology, University of South Africa

Acta Theologica

$201131(1): 72-94$

doi: 10.4314/actat.v31i1.5

ISSN $1015-8758$

(C) UVIUFS

<http://www.uovs.ac.za/ActaTheologica> 
History has the ability to keep our ankles in chains, despite our aspirations to run. Most of our present crises (be they economic, socio-political or the daily trauma of violence and conflict) are the fruit of a historical harvest; a confirmation of the truism that, in spite of the good intentions of the harvesters, one can reap only what one sows (Pillay 1991:1). This is true of our immediate past $^{1}$ and the legacy from previous generations. Afrikaners (white South Africans whose native language is Afrikaans) stand accused by the world and their fellow South Africans of a long list of charges that boils down to Apartheid and its legacy, ${ }^{2}$ and of using their unique religion as an ideology to gain political, social and economical power. Violating the principles of the Christian faith to serve the Church as an institution or the political agenda of the government, or both, puts a question mark behind the identity and integrity of Afrikaners as a Calvinist-born nation (Meyer 1940:27). ${ }^{3}$ This leads to conflict, anxiety and insecurity among Afrikaners and persistent hostility towards them.

As anxiety levels were pushed past reasonable limits by the 'out in the cold' experiences of the last two decades, ${ }^{4}$ Afrikaners in general react by shrinking their perspective, tightening the circle and shifting the burden (Steinke 2000:43), effectively paralysing themselves. Anxious people do not respond rationally and are unable to function normally. Their actions are automatic and reflexive (Steinke 2000:5), preventing them from searching for resourceful and flexible ways of dealing with trauma. Therefore, the well-known statement of Rosenberg also applies to Afrikaners:

1 Failure to provide a better life for poor voters is beginning to haunt the government. See for example: Broken promises spark service delivery riots (Times Live 2009) and Why do we deserve the worst? (Nkuna 2009).

2 Sixteen years after the first democratic elections, Apartheid still acts as a scapegoat. In March 2009, Finance Minister Trevor Manuel said that Apartheid destroyed the spirit of enterprise in South Africa (Independent Online 2009). In July, the general secretary of Cosatu, Zwelinzima Vavi, blamed the structures of Apartheid for the current state of the education system. One of the online comments reads: '[T]he point is Mr Vavi is correct. Apartheid is to blame for all the misery in South Africa' (Mail \& Guardian online 2009).

3 Among other things, Afrikaners shared an ox wagon trek, civil war, war against empires, war with indigenous people and a gold rush with other nations that formed during the same period in other parts of the world. However, unlike these nations, there were no public saloons, bar girls or shooting in the streets. Huge churches were built in each town, and conservative Calvinism directed the community.

4 A new chapter that was added to the book of Hermann Giliomee (The Afrikaners: Biography of a people. 2009), updates the events up to the 2009 elections. Minority groups, especially whites, were ignorant of the key ANC policy documents and were consequently shocked and dismayed at the ruling party's interpretation of the Constitution and the continuing deconstruction of democracy. 
Nations [the Afrikaners], like [and] individuals [each individual member of this group], need to face up to and understand traumatic past events before they can put them aside and move on to normal life (Rosenberg 1996:xviii).

It is a major challenge to change the convictions of those who wish to believe their own interpretation of events (MacMillan 2009:87). Yet, historians have as their first task the duty to explain and prepare people to consider alternatives (Giliomee 2003:35). The fact that Afrikaner history and Christianity cannot be separated and Afrikaners have strong convictions regarding both these issues makes this no easy task. Many Afrikaners still cling to a 'holy' history perspective ${ }^{5}$ (cf. Den Boer 1966:33; Van Jaarsveld 1961:228), which results in attitudes unacceptable to fellow South Africans and the international community.

The international community played a major role in constructing the course of history in South Africa during the last part of the twentieth century (cf. Ackermann 2004:5; Goodsell 2007:109). A crucial mistake the Westernorientated international community often makes is to think that the lives of the large majority of ordinary people change for the better when western concepts like freedom and democracy replace oppressive regimes and that other communities actually treasure and value these concepts with the same affection. ${ }^{6}$ The South African population, with its mixture of races, cultures and ideologies, highlights this problem for the international community and reminds the Afrikaner community that a nation's dealing with its past is never entirely within its own control (Evans 2003:9).

The first part of the article focuses on the unique character of Afrikaners. National identity refers to things that are repeatedly the same, to such an extent that they create a oneness through which recognition and classification can be done. From 1652 until the British occupation in 1806, patterns were formed that were burned into the nation during the next 150 years (Erlank 1952:9). The spotlight will be on the second period. Finding primary sources

5 In 1979, when the prominent Afrikaner historian, F A van Jaarsveld, attempted to give an inclusive interpretation of the history surrounding the Battle of Blood River, he was tarred and feathered by conservative right-wing Afrikaners.

Since 1994, the number of Afrikaner students and learners enrolled for History as a subject have declined rapidly. An ever growing number of parents also indicate that the History curriculum (compulsory for the lower grades) used in public schools is one of the main reasons for sending their children to private/church schools or to make use of home schooling service providers.

6 MacMillan (2009) uses the example of Vietnam to illustrate that it is dangerous to assume that other communities share western thoughts on democracy and freedom (p. 114), but fails to see that she and many others apply this same onesided view on the situation and people of South Africa (p. 25). 
regarding the national identity of Afrikaners presents a problem. One of the reasons could be that literacy levels among Afrikaners were low. Under the British rule, Afrikaners were regarded as an inferior race (Adam \& Giliomee 1979:33), which resulted in them not willing to talk or write about themselves (Van Jaarsveld 1981:2). A number of the diaries, correspondence, handwritten hymnbooks and other primary sources describing the lives and thoughts of the Transvaal pioneers went up in smoke when farmhouses were burned during the Anglo-Boer War (Van Rooyen 1940:27).

The work of Afrikaners who later looked back and developed a prototype, heroic example of the Afrikaner for current generations to follow (Coetzee $1977: 152,153)$ is often countered by the judgement of outsiders who wrote down their observations (mainly during the nineteenth century), supplying us with both sides of the coin. Surprisingly, though, the same characteristics that these groups identified about past generations, are observed in the 20th and 21st century because Afrikaners '...present a remarkable instance of a population that has been almost stationary for two centuries in manners, customs and education' (Garrett-Fisher 1900:34).

The Protestant Church functioned as a partner to economical and political powers for the greater part of history since the European settlement at the Cape. However, the Afrikaner nation developed into a Christian nation, largely without and in spite of the official Church. This will be explained next. The Afrikaans-speaking Christian churches' abuse of Afrikaner religion to become a political and economical power cannot be underestimated or ignored. All South Africans were affected. These churches contributed significantly to the current trauma and the high levels of cognitive dissonance experienced by Afrikaners.

Finally, before attempting to find a possible way to face the past, it is necessary to link these issues with current attitudes and behavioural patterns of Afrikaners. Reactive behaviour, symptomatic relief, a shrinking perspective, shifting of the burden and tightening of the circle (as identified and described by the systems theory), can all be found in current day-to-day lifestyles of Afrikaners.

Searching for an inventive and practical way of facing our religious past, ${ }^{7}$ the focus must turn back to the core identity of the Afrikaner nation. By not concentrating on what separates us, but on what we share, it should be possible to shift the attention from past grievances ${ }^{8}$ to our greatest asset:

7 One of our goals as historians is to clarify the foundations of contemporary society and to identify remedial actions necessary for enhancing a collective awareness of society as a moral community (Nytagodien \& Neal 2004:381).

8 History is too often employed to focus on past grievances. As a result, identities are often conceived in terms of a 'culture of grievance' in which the group's most 
Christian foundations. However, faith transforms people, not structures and systems. Seemingly small changes in people can produce large and significant changes in the system. This is no instant solution. The support and patience of other South Africans and the international community would probably be stretched to their limits, as the lack of unity and the characteristic stubbornness within the Afrikaner community will definitely complicate and attempt to sabotage the whole process.

By working backwards through the issues that are explained above, the Afrikaner nation will be able to recover from the symptoms of continuous and extreme stress. Unfortunately, this implies a confrontation with Afrikaansspeaking churches. Afrikaners need to identify for themselves where and why some of their views and those of the churches regarding history, theology and traditions are not in line with basic Christian principles. Only when this process is completed, there could be progression. The next step would be to recover our identity and integrity through the imperative lens of meta-memories from salvation history (Volf 2006a). All Christians share the same identity (a new identity given by Christ), regardless of their nationality, language or history. The Calvinist-born Afrikaner nation, displaying its true Christian (New Testament) identity, would repent for past sins by thinking and acting differently and becoming an influential, changing force to a better future for all living in South Africa.

\section{AFRIKANER IDENTITY}

Characteristics of a nation have a sense of permanence, continuing from one generation to the next to form a pattern that is detectable in each generation (Wilcocks 1945:287). Over time, characteristics of Afrikaners have melted into one solid mass, making it nearly impossible to distinguish between the character, religion and world view of the nation (Erlank 1952:12).

Afrikaners are generally classified as being religious, conservative, strongminded individuals who cling to a patriarchal system and who are cunning, aggressive and have an ever-lurking sense of humour. However, these characteristics are often also seen in a negative way. Words like sectarian, narrow-minded, stubborn, male dominant, dishonest, aggressive, arrogant and hempen humoured are used to show the darker side of the nation. The positive and negative aspects of these characteristics (with the exception of the Afrikaner sense of humour, which, although often frowned upon, is not essential to this investigation) will be explained briefly next.

important characteristic is their status as historical victims (Black 2008). 


\subsection{Unconsciously religious or sectarian}

The Dutch East Indian Company (DEIC), which was not exclusive in recruiting its servants, colonised the Cape in 1652 (Le May 1995:3). Among the settlers were people from Sweden, Germany, Scandinavia, Flanders and France (Preston 1989:15). These colonists used their faith as a form of identity, calling themselves Christians to distinguish them from the indigenous population and the slaves (Giliomee 2009:41).

The DEIC exercised its authority over the Church in an Erastian manner (Gerstner 1991:187). Ministers of religion, comforters of the sick and schoolteachers were all employees of the DEIC. This linked politics, religion and education into a tight partnership. By 1780 , the colony was still administered as if it was only a refreshment station. The administration and government was basically the same as it had been a century before and was still located in Cape Town.

The year 1657 was the birth year of the Afrikaner nation when nine farmers, no longer in the service of the DEIC, were given farms to provide for themselves and sell their stock to the company (Van Jaarsveld 1971:8). During that time, the Afrikaners developed without government-provided education and religion (Du Toit, Giliomee 1983:3). The Bible, and not the Church, was the one thing that bound people into a nation (Wichmann 1941:3). The Church did not have a great influence on the lives of the isolated people living outside the sphere of the DEIC, but God and his word was part of every aspect of their lives (Nepgen 1938:58).

One of the most significant characteristics of the Reformed tradition was its aim to bring theology down to the popular level (Gerstner 1991:114). The Dutch Reformed tradition of the Continuing Reformation or Dutch Pietism (Oliver 2005:125) excelled in this area with books on the level of general readers that followed the basic loci of systematic theology. Together with the Bible, the theological house books greatly influenced the thoughts and actions of Afrikaners (Oliver 2005:110). The heavy emphasis on catechesis and knowledge of the contents of the Bible ensured that religion became part of the Afrikaner identity. Rose identified religiosity as the most important characteristic of the Afrikaner: "He is, so to say, unconsciously religious; it simply never enters into his head to be otherwise" (Rose 1902:11).

Afrikaners generally identify themselves as Calvinists, but one must be careful not to equate the French Reformer's theology with those of later Calvinists (Compier 2007:216). Afrikaners reached their own conclusions on doctrine, morals and interpretation of the Biblical message. ${ }^{9}$

$9 \quad$ The Biblical founding of Apartheid can be seen as proof (Hanekom 1948). 
Exactly why Afrikaners began to see themselves as a modern counterpart of an Old Testament tribe (Calpin 1944:17) and allow their Christian heritage to fade cannot be explained adequately by the fact that they saw similarities between their own living conditions and those of the tribes of Israel. The influence of Pietism probably played a major role in developing the concept of a nation that has a special relationship with God. The fact that Afrikaners distanced themselves actively from people not living according to the Reformed dogma (Stuart 1854:211) contributed to the 'holier than thou' perception others had of them. "They have persuaded themselves by some wonderful mental process that they are God's chosen people" (Mackenzie 1899:158). Fatal flaws like the exclusion of other population groups by assigning them the status of inferior beings (Volf 2006b:24) clearly show how easily religion can develop into heresy.

After the Anglo-Boer War (1899-1902), the influence of Kuyper's New Calvinism ${ }^{10}$ was incorporated into the Puritan-Reformed theology, resulting in a syncretistic civil religion (Nieder-Heitmann sa:185). The shell of Puritanism remained in the shape of Sabbatarianism and other formalistic prohibitions up to the 1980s (cf. Oliver 2008:310). The idealistic (Calvinistic) concept of a theocracy led to the implementation of numerous laws after 1948. Biblical concepts such as election and covenant were given a national, racial and cultural interpretation (Richardson 2001:4). It must be remembered, though, that the covenant concept was also used by other nations (cf. Akenson 1992), and this way of working with Biblical concepts is not unique. The Afrikaners' excellent knowledge of the Bible became a handy tool in the hands of the Apartheid government to guarantee submission to authority and to create a sense of belonging with the aid of familiar Christian symbols, laws and customs with which the nation could identify and which they would be willing to defend with their lives in the Bush $\mathrm{War}^{11}$ that lasted for 23 of the 33 years that Apartheid officially existed under an independent Afrikaner government (South Africa became an independent republic only in 1961).

10 Kuyper referred to 'sovereignty in one's own sphere' and declared that each nation's separateness was ordained by divine will (Each 1989:43).

11 The South African Border War, also known as the Bush War or the Namibian War of Independence, refers to the armed conflict that took place in South-West Africa (now Namibia) and Angola between 1966 and 1989 between the South African Defence Force (which numbers were strengthened by compulsory national service for all white males) and its allied forces (mainly UNITA) on the one side and the Angolan government, the South-West Africa People's Organisation (SWAPO), and their allies - mainly the Soviet Union and Cuba - on the other. 


\subsection{Conservative or narrow-minded}

'The Boer is a born conservative' (Froude 1886:38). 'They are a deliberate and slow people, not given to enthusiasm for new ideas' (Froude 1886:34). Generation after generation used the same farming methods (Wilcocks 1945:294). Everything that was intended to change or improve their lives was frowned upon as either 'English' or coming from the 'antichrist' (Weilbach \& Du Plessis 1882:24). Obedience to religious laws like the Ten Commandments had a positive impact upon society.

The laws of the Transvaal (1865) were upon the whole as good as those of any other country, but for want of a police it was impossible to enforce justice in all cases, yet great crimes were exceptionally rare, for nowhere in the world was the moral law of greater force than among the farmers of the South African Republic (Nixon 1880:208).

When seen from the other side, people got frustrated with Afrikaners who, due to their narrow scope of reference, were not open to debate or conviction. They were not interested in secular books or ideas because they found in the Bible all their theology, history and science - all the literature they needed (Regan 1896:3). "[They] ... have retained the full habits, alike in thought and action, of their forefathers ... secluded themselves from possible influences of change" (Garrett-Fisher 1900:35). Reverend Van der Hoff exclaimed, "I sometimes wonder if they can think at all" (LK No. 249: Van der Hoff to Lauts, Potchefstroom, August 1, 1853).

\subsection{Strong-minded individualism or stubbornness}

Pioneers are able to act independently in unknown and uncertain circumstances. Living thousands of miles from Europe at the southern tip of Africa with its unknown weather patterns and unique challenges like insufficient communication systems, poor roads and slow and dangerous means of transport provided challenging opportunities for Afrikaners to develop new skills. Afrikaners became independent and self-supportive (Froude 1886:37). Men were not only stock farmers; they were also blacksmiths, sharpshooters, wagon makers, shoemakers, builders, carpenters, thatchers, tanners, transport riders, painters and furniture makers (Stuart 1854:210). Everyone was a jack of all trades, and so were the women who made their family's clothes and could do anything from baking bread in an anthill to making soap and candles from the fat of a hippopotamus and loading firearms. They also acted as nurses and teachers.

The resourceful creativity of Afrikaner minds can be traced like a golden thread running from the time of the first free burgers and the farmers fending 
for themselves in the eastern border districts, through the traumatic events of the Great Trek and the numerous wars up to the time of isolation and sanctions and the Bush War of the twentieth century. With great success, Afrikaners managed to invent and implement whatever was needed. ${ }^{12}$ This created a sense of superiority, a feeling that they did not need others and a stubborn refusal to ask for help or accept advice or instructions from others.

Even to the Afrikaners themselves, the negative impact of this part of their character is usually evident. Schism and power struggles severely handicapped the development of the nation and led to the loss of countless lives. ${ }^{13}$ Their strong-minded individuality, unwillingness to follow where others lead and pride always manage to spark division and discord among Afrikaners (Wichmann 1941:2). After the Great Trek, three different republics and three different Afrikaans-speaking churches developed within a decade or two. This disunity caused many problems. Fanatic groups were willing to fight against each other to prove their point (Pont 1968:197), and although political unity was eventually attained, the schism among the Afrikaans-speaking churches still exists.

\subsection{Patriarchal system and male dominance}

On his journey through the ZAR in 1853, Reverend Neethling of the Cape was delighted to find 'living faith' on the farms where the people lived like the patriarchs of the Old Testament (Stuart 1854:408).

In the Netherlands and South Africa, the gesin (household or immediate family, but no real English equivalent) has its own special meaning. The gesin formed the cornerstone of society, and everyone had his and her own place and designated job within the structure (Van Zonneveld 1987:24). 'I never saw so much unity, childlike obedience and respect woven together' (Stuart 1854:208).

12 The Afrikaans saying in this regard, ' $n$ Boer maak ' $n$ plan', can be translated as a Farmer/Afrikaner will always find a way to get around a problem, even if he has to invent a solution. Several South Africans are famous for their inventions (e.g. Prof Chris Barnard who successfully transplanted a human heart) and during the years of isolation, KRYGCOR developed weapons like the Rooivalk Helicopter of which the patent was later sold to a European country. Also see the invention web page of the University of Stellenbosch (http://www.innovus.co.za/pages/english/newsand-events/our-newsletter.php).

13 The Great Trek could have had a smaller body count if people had been less stubborn and listened to the advice of others - the history of Italeni serves as a good example. 
The father and his married children stayed together on gigantic farms, each with its own house and garden and cattle. It was the man's duty and honour to provide for the needs of his family. The patriarch was respected inside and outside the family. Afrikaners saw the family as an institution ordered by God; therefore, the authority of the father was respected even by married children (Keyter 1940:86).

It is difficult to explain the traditional role of Afrikaner women. As mothers, they had absolute authority.

There alone you will find obedience to parents as strict as among the ancient Sabines, the severa mater, whose sons fetch and carry at her bidding (Froude 1886:37).

As wife, her opinion had great influence. Giliomee (2009:169) says that women were the driving force behind the Great Trek, and other authors confirm their influence although they did not play a prominent public role:

The Transvaal War of 1881 was largely a woman's war: it was from the armchair beside the coffee-table that the voice went out for conflict and no surrender (Schreiner 1923:201).

I have the greatest respect for the men living in Transvaal, but for the Transvaal women, I feel admiration of the highest level. They are serious in praying, wise, brave when fighting and have an absolute ennobling effect on the men and youngsters ... This brought a generation, a nation to be the heroes of Bronkhorstspruit, Laingsnek, Schuinshoogte, Spitskop and Krugersdorp, and gains the respect and admiration of the world (Rovers 1896:16, 7).

These traditional roles were shattered after 1994. Large numbers of Afrikaner men lost their jobs, ${ }^{14}$ and many were unable to find other means of income. This resulted in extreme emotional stress as countless households were forced to adjust to mothers working long hours, providing the family income and fathers who judged themselves as failures, to take the household tasks upon their shoulders. The long-term effects of these changes on the identity of Afrikaners will become clear only with the passing of time.

14 About 117000 white civil servants left their jobs between 1998 and 2002 after receiving compensation for leaving early. Most of these were Afrikaner men (Giliomee 2009:688). 


\subsection{Cunning or dishonest}

According to Leyds (1885), quoted by Giliomee (2009:190), the national character of Afrikaners appears to be cunning dishonesty or dishonest cunning. This characteristic came with the first settlers:

To compensate for their low pay, many of the Company's staff stole from their employer, embezzling or trading for their own account (Giliomee 2009:3).

Years later, in the Transvaal, Younghusband (1890:245) wrote that they were 'deficient in honesty and veracity'. Today, Afrikaners do not generally see themselves as dishonest or cheating, but when confronted directly, they normally do admit that they often violate traffic laws and declare only what is necessary on their income tax forms.

\subsection{Aggressive and arrogant}

Afrikaners do not trust strangers and immediately become defensive in a situation where they are not the masters (Meyer 1940:118). They sometimes act impolitely (Meyer 1940:118). They have

a sturdy self-reliance, a grim courage in the face of danger and a sternness from which the native races have often had to suffer (Bryce 1900:56).

Owing to the lack of contact with strangers and the negative experiences they had when meeting strangers in the past (who either wanted to kill them or take the land from them),

[a]Imost without exception, Boer contacts with other peoples have served to evoke uneasiness and fear, however much these fundamental responses might be masked by superficial aggressiveness (Paterson 1957:279).

Although Afrikaners will not easily admit to this, aggressiveness is currently often used as a mask to hide emotions like fear, uncertainty, distrust, being caught doing something stupid or against the law (like traffic violations), or not willing to admit mistakes, misperceptions, grief and feelings of loss and a general inability to cope (Jansen 2009:48).

When confronted with their actions and attitudes, Afrikaners are either unwilling or unable to do intensive, honest introspection. The fact that most Afrikaners have a very good knowledge of their history should enable them to identify the reasons behind the development of certain characteristics and their negative impact. However, their perception of history, which will be 
discussed next, forms an obstacle that prevents them from recognising that, for a Christian, everything, including who and what you are, must be in line and compatible with New Testament principles of Christian faith.

\section{INTERPRETATION OF HISTORY}

Afrikaners see themselves as victims and underdogs, highlighted by the grievances about Slagtersnek, ${ }^{15}$ the events that led to the Battle of Blood River and the suffering of Afrikaners under the British during the Anglo-Boer War. The centenary celebrations of this event proved that the scars and memories of grandparents and great grandparents were treasured as if the war had ended in 2003 and not a hundred years earlier. The observation that Afrikaners 'still fight the Boer War in their sleep' (Brown 1966:201) was revived by the celebrations.

It is interesting to note that the personal scars and memories from the Bush War, which ended only a few decades ago and formed part of the actual experiences of the current middle-aged generation, started to emerge only recently. ${ }^{16}$ It seems as if the trauma and impact were so intense that a significant lapse of time was needed before these memories could be faced.

Events that reveal Afrikaners as perpetrators or villains are simply ignored - an example of cultural amnesia. Historians chose what ought to be remembered and what not. In general, Afrikaners were not interested in the scars and memories of their enemies, proving that feeling like a victim of injustice in one situation does not make us less likely to commit an injustice against someone else, nor does it make us more sympathetic to the victims of our injustice (Travis \& Aronson 2008:192).

Afrikaners see themselves as a nation that raised from poverty and defeat to establish an independent nation, but that was traumatically forced to return to underdog status again after 1994. When pressed about Apartheid, the classical reactions of cognitive dissonance ${ }^{17}$ emerge. A large group of Afrikaners holds on to the perception that the achievements of Afrikaners were the result of hard work through their superior skills. Afrikaners did nothing wrong when they implemented Apartheid. The problem was the agitators who

15 The Slagtersnek rebellion had a long run-up. Finally, five Afrikaners were sentenced to death, but four of the ropes broke. The people watching saw this as a sign from the Lord that their lives should not be taken, but the English officer used other ropes.

16 Although it was one of the largest ideological Cold War conflicts, little is known about the South African Bush War (1966-1989). www.geocities.com/sa_bushwar/. \{2008, 5 December $\}$.

17 Cognitive dissonance is explained in the work of Travis and Aronson 2008. 
were inspired by external agents who tried to destroy western civilization and culture with their evil, atheistic schemes (Jansen 2009:38). A second group of Afrikaners admits that Apartheid was wrong. They also see it against the backdrop of external and internal threats to peace and stability and are in general embarrassed by the revelations of Apartheid victims. This group often acts impatiently and wants the whole thing to be left in the past and for the victims "to get over it" (Jansen 2009:39). A relatively small group of Afrikaners admits that terrible things happened during Apartheid, but most of them see themselves as innocent bystanders, or they shift the responsibility to the government (Klandermans et al. 2008:338) or the small group of influential Afrikaners known as the Broederbond. ${ }^{18}$ Afrikaners in all three groups are experiencing emotions of defeat (Jansen 2009:45).

\section{THE CHURCH}

Although the Afrikaner nation came into being as Calvinists, people did not associate closely with the official Church. The colonial Church functioned as a state department with Church offices neatly woven into the ranking system of the DEIC (Nieder-Heitmann sa:178). After the British occupation, the government retained its supervision over the Church. The 1837 General Synod declared the Great Trek a rebellion against the government and forbade all preachers contact with or service to the Voortrekkers north of the Orange River (Spoelstra 1988:46, 47).

When the Voortrekkers proclaimed their republics, the Church became a vehicle for Afrikaner education and culture. The Afrikaner Church failed in the execution of the Great Commission of her Lord (Staples 1980:35): The South African Missionary Society was founded only in 1799 (Gerdener 1959:55), but missionaries from outside South Africa did most of the early missionary work. The Voortrekkers and their children, although they saw themselves as the 'chosen people of the Lord', did not do missionary work (Van Jaarsveld 1962:245).

The Hervormde Kerk ... firmly opposed all missionary work. The Dopper majority accepted missionary work as long as it avoided common worship ... The pro-British DRC [Dutch Reformed Church or Nederduitse Gereformeerde Kerk] tended to be much more liberal in

18 Between 1918 and 1994, the Afrikaner Broederbond (meaning Afrikaner Brotherhood), was a secret, exclusively white male Protestant organization in South Africa that had great influence in politics, religion, social matters and the economic policies of the country. 
their attitudes towards non-Afrikaners but, while in principle in favour of missionary work, did very little in practice (Giliomee 2009:179).

None of the three Churches in the ZAR had missionaries in the field before 1899 (Van Jaarsveld 1962:245).

Thirteen years after Voortrekkers had established their new homeland north of the Vaal River, there were three official Afrikaans-speaking churches. An attempt to reconcile two of the churches (spurred on by the success of the Transvaal War - 1878-1882) failed and "the remaining decades of the century were occupied by inter-church bickering and abortive reconciliation" (Patterson 1957:187). After the Anglo-Boer War, religion was turned into ideology and the Church shared the government's power and control by ensuring that laws were passed to shape and discipline society to conform to Christian values and laws. This resulted in a society in which everyone knew about Christian values and moral norms. Soon it became the responsibility of the government and the churches to see to it that these were adhered to. Individual commitment to faith, which to a large extent was both the founding model of the Afrikaner nation and the protection of their identity, began to fade. Afrikaners' day-to-day practices and customs were no longer based upon personal religious values and commitment. For most people, Christianity became a mere label (cf. Froise 2004:7, 8).

In 1987, another schism appeared when the Dutch Reformed Church declared that Apartheid had been a mistake..$^{19}$ Currently, the unification of the Dutch Reformed family of churches seems unlikely, and unification of the Afrikaans-speaking churches is unthinkable. Internal conflict and power struggles are some of the symptoms showing the need for drastic reformation of the Afrikaans-speaking churches (Oliver 2009:169). Sometimes one gets

19 By 1948, the union between the Dutch Reformed Church (NG Kerk) and the State was well established, and it was said that 'the Church is the Nationalist party at prayer' (Ferm 1986:62). Historically, the DRC enthusiastically supported Apartheid (Rich 2001:42). In 1942, a DRC theologian, G. Cronje, coined the term and used Scripture to support racial separation. In 1948 the official church newspaper said that 'Apartheid can rightfully be called a church policy' (Lalloo 1998:43). In 1950, the DRC held a conference to develop a 'native policy', urging the Nationalist government to implement Apartheid in the quickest possible way. In 1975, the DRC published a Scriptural defence of Apartheid and reaffirmed the document in 1979. In 1986, Church and Society declared that the attempt to base Apartheid on Scripture was a mistake.

The new church (APK) did not agree that Apartheid was a mistake. The other Dutch Reformed Church (NH Kerk) agreed with them and refused to renounce Apartheid until 2010. These attitudes and examples by respected churches and spiritual leaders contribute to the display of cognitive dissonance by church members. 
the impression that the current leaders do not care about the current downward spiral. ${ }^{20}$

The only positive contribution made to society by Afrikaner churches after the Anglo-Boer War was on a social level, made with the help of voluntary workers that carried the Afrikaners through a series of traumatic events like the flu epidemic of 1918 and the problem of poverty of whites more than a decade later (Symington 2005). The Christian Church is still the strongest and largest non-governmental organisation in South Africa (Erasmus 2005). However, it needs to re-identify its main purpose to free itself from being reduced to a social worker. ${ }^{21}$

\section{CURRENT ATTITUDES AND PATTERNS}

Afrikaners use a number of strategies to cope with the current situation in South Africa. Reactive behaviour, symptomatic relief, shifting the burden, tightening the circle and shrinking of perspectives (Oliver 2007) are all negative and counterproductive dead-end escape routes identified by the systems theory.

A quick-fix symptomatic relief option was chosen by thousands of Afrikaners when they formed part of the $15 \%$ of the population that emigrated during the last two decades (Giliomee 2009).

Others implemented the strategy of self-victimization, by declaring themselves innocent victims. The weight of guilt and responsibility is put on the shoulders of others, usually the government. The government should take responsibility for the chaos because they implemented a too liberal constitution. ${ }^{22}$

One of the most common reactive responses used by Afrikaners is the 'I told you so' attitude. Confronted with a problematic situation, Afrikaners would fold their arms and sit back, refusing to respond positively.

20 On average, the traditional Afrikaans-speaking churches lose more than 1000 members annually (Oliver 2006:117-134).

21 In 2007, the government provided money to religious groups to help with early child development, housing and literacy programmes on HIVIAIDS (Jackson 2007).

22 The 1996 South African Constitution and Bill of Rights are 'truly modern' (Goodsell 2007:109), but most South Africans (including Afrikaners) are very conservative. The Bill of Rights does not reflect the sentiments of South Africans. The abortion act can serve as an example: Market research conducted in 1995 found that 78,8\% of ANC supporters are opposed to legalised abortions (Gevisser 1997:250). The ANC experienced a public split of opinion within its caucus when Parliament passed the choice bill. 
These actions, which are fuelled by high levels of anxiety, emphasise the need for a fresh approach and creative actions. Being creative and capable of inventing solutions to problems, Afrikaners can play an important role in reversing some of the country's problems.

\section{WAYS TO CONFRONT THE PAST}

Afrikaner history, if approached and taught from a new angle, should be able to encourage the current generation not to give up on themselves, but to face the situation positively.

Although national characteristics have a sense of permanence, their harmful impact can be reduced once the negative aspects are identified and confronted. Academics like De Gruchy and Villa-Vicencio, theologians like Beyers Naude and historians all tried to bring the Afrikaner nation to dialogue with its past. It is possible to identify where and how things went wrong and then to try to steer away from it consciously, using the same characteristics in a positive way to identify and produce positive alternatives.

Reformers coined the principle of semper reformanda, but this guideline is of no use if it is not practised constantly. The fact that other Christians are able to label Afrikaner religious history as sectarian or hypocritical must activate intensive self-evaluation and testing against Biblical principles. If done honestly, this would bring Afrikaners in direct confrontation with Afrikaansspeaking churches and some of their own treasured presuppositions. Longstanding 'traditions' like missionary attitudes must be revealed for what they really are - heresies. The false identity of the Church, being a political, economical and social power hiding behind social actions, must be exposed and destroyed.

Believers need to reclaim the power of their faith from the hands of the Church as an institution. Christianity is not an ideology and cannot be used in this way. Faith, not institutions, transforms people. This lesson is clear from the pages of the New Testament as well as the Reformation era. Seemingly small changes in people can produce large and significant changes to the system. Therefore, we cannot wait around for Afrikaans-speaking churches to have a moral conversion, for Church leaders to have personality transplants or new insights that will cause them to admit error and deconstruct the institution of the Church to revive faith and its power among Afrikaners. This would mean that Church leaders would lose their power, income, security and credibility. The history of the Protestant Reformation teaches us that this is not likely to happen. Therefore, Afrikaners must take stock and decide on a plan of action to face their past and the part the official Afrikaner churches played to be able 
to make a positive mind shift towards the future of their Christian religion and their role in the country.

Confrontation with our religious past would also include a thorough investigation of the traditional interpretation of history. If Christianity is used as a framework to look at history, all Christian principles should be implemented for all sides of the story. By correcting the focus point to zoom in on Christ and Christian faith (not personal interpretations or bias), the rest of the picture would need only minor adjustments, corrections and explanations to become understandable, usable and a positive encouragement for current and future Afrikaners to stay true to their identity and calling. However, this would be very difficult, and as church leaders and school teachers cannot be expected to lead the way, other means like the gesin would have to be targeted to carry the message.

Only after Afrikaners themselves have completed this process successfully, the focus can turn back to the concept of the rainbow nation - the fact that we are all South Africans. By not concentrating on what separates us, but on what we share - our faith in Christ - it should be possible to shift the attention to positive change and development of individuals and society.

The eyes of the international community and fellow South Africans are still on every move made by the Afrikaners, despite the fact that 16 years have elapsed since the first democratic elections. Facing their religious past, and constantly adjusting their direction to stay in line with their faith (semper reformanda) Afrikaners would repent, not by feeling bad but by thinking and acting differently and opening a new path into the future.

Working through the issues that are explained above, the Afrikaner nation will be able to venture once again as pioneers onto new and unknown paths. Exciting opportunities would await the Calvinist-born Afrikaner nation, displaying their true Christian identity (based on New Testament principles).

\section{BIBLIOGRAPHY}

ACKeRMANN, L.W.H.

2004. Menswaardigheid na tien jaar van regstaatlikheid in Suid-Afrika. 'n Toespraak ter inleiding van die tema: Die verwesenliking van menswaardigheid in die huidige tydsgewrig. Noordwes-Universiteit 16 Maart 2004.

Adam, H. \& GiLiomee, H.

1979. Ethnic power mobilized: Can South Africa change? New Haven: Yale University press. 
AKENSON, D.H.

1992. God's peoples: covenant and land in South Africa, Israel and Ulster. New York: Cornell University Press.

BLACK, J.

2008. The curse of history. London: Social Affairs Unit.

Brown, D.

1966. Against the world. A study of white South African attitudes. London: Collins.

BRYCE, J.

[1897] 1900. Impressions of South Africa. New York: Macmillan.

CALPIN, G.H.

1944. There are no South Africans. London: Nelson.

Coetzee, J.H.

1977. Die Afrikaner: Definisie en konsep. Koers XLII (3):146-165.

COMPIER, D.H.

2007. Jean Calvin. In K. Pui-lan; D.H. Compier \& J. Rieger (eds.), Empire and the Christian Tradition. New readings of classical theologians. (Minneapolis: Fortress Press), pp.215-227.

Den Boer, W.

1966. Terminologie en waardeoordeel in de geschiedwetenschap. Standpunte 19(4):23-35.

Du Tolt, A. \& GiLIOMEe, H.

1983. Afrikaner political thought. Analysis and documents. Volume 1:1780-1850. Cape Town: David Philip.

$\mathrm{EACH}_{\mathrm{AC}} \mathrm{G}$.

1989. The Afrikaners. Their last great trek. London: Macmillan.

ERASMUS, J.

2005. Who are the people with no religion? In J. Symington (ed.), South African Christian handbook 2005/2006 (Cape Town: Lux Verbi), pp. 87-101.

ERLANK, W. J. D P.

1952. Die patroon van ons volkskarakter. Johannesburg: FAK.

Evans, R.J.

2003. Redesigning the past: History in Political transitions. Journal of contemporary history, 38(1):5-12.

FERM, D.W.

1986. Third world liberation theologies: An introductory survey. New York: Orbis Books. 
FroISE, M.

2004. Is Christianity in South Africa a label or a spiritual and ethnical value system? A study of Christian adherence in the city of Welkom. Unpublished DTh thesis. University of South Africa. Pretoria.

FROUDE, J.A.

1886. Oceana or England and her colonies. London: Longmans.

GARRETT-FISHER, W.E.

1900. The Transvaal and the Boers. London: Chapman Hall.

Gerstner, J.N.

1991. The thousand generation covenant. Dutch Reformed covenant theology and group identity in colonial South Africa, 1652-1814. Leiden: Brill.

Gerdener, G.B.A.

1959. Die Afrikaner en die sending. Cape Town: NGK Boekhandel.

GeVISSER, M.

1997. The ANC's great divide. The Nation. 17 February, p 25.

GILIOMEE, H.

2003. Rediscovering and re-imagining the Afrikaners in a New South Africa. Autobiographical notes on writing an uncommon biography. Itinerario 27(3/4):9-48.

2009. The Afrikaners. Biography of a people. Cape Town: Tafelberg.

GoodselL, E.E.

2007. Constitution, custom and creed: Balancing human rights concerns with cultural and religious freedom in Today's South Africa. Brigham Young University journal of public law 21:109-152.

HANEKOM, T.N.

1948. Apartheid as Kerkbeleid. Die Kerkbode 22 September 1948.

INDEPENDENT ONLINE

2009. 29 March. [Online] Retrieved from: www.iol.co.za/general/news/newsprint. php?art_id=nw20090329202431462C952144 [2009, 29 March]

JACKSON, N.

2007. Staat gee geld vir armes in pakt met godsdiensgroepe. Beeld 25 July, p. 4.

JANSEN, J.D.

2009. Knowledge in the blood. Confronting race and the Apartheid past. Cape Town: UCT Press.

KeYTER, J. DE W.

1940. Die huwelik en gesin. Bloemfontein: Nasionale Pers.

Klandermans, B, Werner, M. \& Van Doorn, M

2008. Redeeming Apartheids' legacy: Collective guilt, political ideology, and compensation. Political Psychology 29(3):331-349. 
LALLOO, K.

1998. The church and state in Apartheid South Africa. Contemporary politics 4(1):39-55.

LE MAY G.H.L. 1995. The Afrikaners. Oxford: Blackwell.

MAIL \& GuARDIAN ONLINE 2009. Apartheid to blame for education system. 1 July. [Online] Retrieved from: http://www.mg.co.za/article/2009-07-01-vavi-Apartheid-to-blame-for-educationsystem. [2009, 4 November].

MACKENZIE, W.D. 1899. South Africa: Its history, heroes and wars. Chicago Philadelphia: Monarch Book Company.

MacMillan, M.

2009. The uses and abuses of history. London: Profile books.

MeYER, P.J.

1940. Die Afrikaner. Bloemfontein: Nasionale Pers.

Nepgen, C.C.

1938. Die sosiale gewete van die Afrikaanssprekendes. Stellenbosch: Pro Ecclesia.

Nieder-HeitmanN, J.H.

sa. The missionary challenge of Christendom and modernity in South Africa: a Dutch Reformed account. International review of mission. XCII (365):178-191.

NIXON, J.

1880. Among the Boers. Cape Town: Juta.

NKUNA, B.

2009. Why do we deserve the worst? Khayelitsha struggles. [Online] Retrieved from: www.khayelitshastruggles.com/2009_05_01_archive.html. [2009, 4 November].

NowICKI, A.

2004. What went wrong in South Africa? WTO globalization harks back to $19^{\text {th }}$ century imperialism. Z magazine. \{2008, 2 December\}.

Nytagodien, R.L. \& Neal, A.G.

2004. Confronting an ugly past. The journal of American culture, 27(4):375-383.

Oliver, E.

2005. The impact of Christian education on the Zuid-Afrikaansche Republiek. Unpublished DTh thesis. University of South Africa.

2006. Sunday School: Past and Present. Studia Historiae Ecclesiasticae, 32/1:117-134. 
2007. Thoughts on writing Afrikaner church history. Studia Historiae Ecclesiasticae, 33(1):23-40.

2008. Die invloed van die Christelike geloof op die Suid-Afrikaanse samelewing. In die Skriflig, 42 (2):305-326

2009. Suid-Afrikaanse Calvinisme onder die loep. Studia Historiae Ecclesiasticae, 35(2):169-182.

PATTERSON, S.

1957. The last trek: a study of the Boer people and the Afrikaner nation. London: Routledge.

Pillay, G.J.

1991. In quest of a nation: Some historical pitfalls and stumbling blocks. In W.S. Vorster (ed.), Building a new nation: the quest for a new South Africa. (Pretoria: UNISA), pp. 1-14.

PONT, A. D.

1968. 'n Oorsig van die algemene kerkgeskiedenis en die geskiedenis van die Nederduitsch Hervormde Kerk van Afrika. Pretoria: HAUM.

Preston, A.

1989. Suid-Afrikaanse geskiedenis in beeld. London: Bison.

REgan, W.F.

1896. Boer en Uitlander: The true history of the late events in South Africa. London:

Digby Long.

$\mathrm{R} I \mathrm{CH}, \mathrm{G} . P$.

2001. Apartheid and Christianity. TheJournal of Religious Thought: 38-50.

Richardson, N.

2001. Apartheid, Heresy and the church in South Africa. The Journal of Religious Ethics 14(1): 1-21.

Rose, E.B.

1902. The truth about the Transvaal. A record of facts based upon twelve years residence in the country. London: Rose.

Rosenberg, T.

1996. The haunted land: Facing Europe's ghosts after communism. New York: Vintage Books.

ROVERS, J.H.

1896. De Transvalers en hunne heldhaftige vrouwen. Amsterdam: De Bussy.

SCHREINER, O.

1923. Thoughts on South Africa. London: Urwin.

SPOELSTRA, B.

1988. Groot Trek herdenkingsfees: Die godsdienstige en kerklike lewe van die Voortrekkers. Lantern 37(4):45-52. 
Staples, H.E.

1980. The differing roles of church, state and home in teaching faith. Journal of theology for Southern Africa 33:34-39.

SteinKE, P.

2000. How your church family works. Herdon, VA: Alban Institute.

STUART, J.

1854. De Hollandsche Afrikanen en hunne Republieken in Zuid-Afrika. Amsterdam: Tielkemeijer.

TIMES LIVE

2009. Broken promises spark service delivery riots. [Online] Retrieved from: www. timeslive.co.za/opinion/article178964.ece [2009, 4 November]

Travis, C. \& Aronson, E.

2008. Mistakes were made (but not by me): Why we justify foolish beliefs, bad decisions, and hurtful acts. Orlando: Harvest Books.

VAN JAarsveld, F.A.

1961. Lewende verlede. Pretoria: Afrikaanse Pers.

1962. Die tydgenootlike beoordeling van die Groot Trek 1836-1842. Pretoria: UNISA.

1971. Afrikaner, quo vadis? Johannesburg: Voortrekkerpers.

1981. Wie en wat is die Afrikaner? Kaapstad: Tafelberg.

Van Rooyen, G.H.

1940. Kultuurskatte uit die Voortrekkertydperk. 'n Kultuur-historiese studie. Deel 2. Kaapstad: Nasionale Pers.

VAn Zonneveld, P. 1987. Panorama van de 19 e eeuw. De tijd van Romantiek en Biedermeier. Amsterdam: Bulkboek.

VolF, M.

2006a. The end of memory: Remembering rightly in a violent world. Grand Rapids: Eerdmans.

2006b. A theology of embrace for a world of exclusion. In J. Liechty \& D. Tombs (eds.), Explorations in Reconciliation. New directions in theology. (Hants: Ashgate), pp. 22-33.

Weilbach, J.D. \& Du Plessis, C.N.J.

1882. Geschiedenis van de Emigranten-Boeren en van den Vrijheidsoorlog. Cape Town: Saul Solomon.

WiCHMANN, F.A.F.

1941. Die wordingsgeskiedenis van die Zuid-Afrikaansche Republiek. 1838-1860. Kaapstad: Staatsdrukker. 
Oliver South Africa: The arduous task of facing our religious past

WILCOCKS, R.W.

1945. Die volksaard van die Afrikaner. In C.M. Van den Heever \& P de Pienaar (eds.), Kultuurgeskiedenis van die Afrikaner: die eerste beskrywing van die Boerevolkslewe in al sy vertakkinge. 1945-1950. Deel 1. (Kaapstad: Nasionale Pers), pp. 286-308.

YounghusBand, $\mathrm{F}$.

1890. South Africa today. London: Macmillan.

Keywords

History

Afrikaners

Religion

National identity
Trefwoorde

Geskiedenis

Afrikaners

Godsdiens

Nasionale identiteit 